\title{
Have Basic Mathematical Skills Grown Obsolete In The Computer Age: Assessing Basic Mathematical Skills And Forecasting Performance In A Business Statistics Course
}

Thomas C. Noser, Western Kentucky University

John R. Tanner, University of Louisiana-Lafayette

Situl Shah, University of Louisiana-Lafayette

\begin{abstract}
The purpose of this study was to measure the comprehension of basic mathematical skills of students enrolled in statistics classes at a large regional university, and to determine if the scores earned on a basic math skills test are useful in forecasting student performance in these statistics classes, and to determine if students' basic math skills have changed over time. The results showed that 22 percent of the students' final grades in business statistics courses were explained by their scores on this skills test. These findings may be of use to statistics faculty in identifying students who experience difficulties in these courses in the future. The current students' scores were compared to scores from a test previously given to students in 1992/1993. The students from the first group had significantly higher scores than the current group of students.
\end{abstract}

\section{INTRODUCTION}

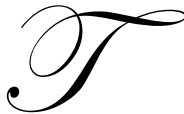

here has long been concern that U.S. students are lagging behind their international counterparts with respect to math and science skills. In the early 1990's, Luther S. Williams, director of education and human resources for the National Sciences Foundation, noted that "beyond any doubt, our students are not even near the best in either science or mathematical skills."

It is reasonable to assume that deficiencies in basic skill areas can impede a student's learning ability and potential. Of prime concern for university educators and administrators is the skill level of their entering freshmen. Deficiencies in fundamental skill areas impact negatively on effective teaching at the university level, and can seriously retard the individual's ability to progress, to succeed. Additionally, resources devoted to remedial work for poor or underprepared entering students are unavailable for those ready to tackle a college level curriculum.

\section{REVIEW OF LITERATURE}

A number of studies in the past have focused on mathematical skills of incoming freshmen (T.W. Jones, 1990, 1991), and upperclassmen (Pinney and Jaska, 1991) in a business curriculum, as well as non-business students (Noser, 1992). Standing (2006) tested university students regarding elementary arithmetic skills, and found that two-thirds failed a test of ten simple items taken directly from a third grade curriculum of 1932 ("failing" meant incorrectly answering any of the problems) (Cornwall, 1999; Hume 1932). Depressingly, test scores decreased progressively with the number of years the subject had spent at the university, and varied by the area of study, with business administration students scoring the lowest. Additionally, performance was positively correlated with self- 
rated math ability and self-predicted test scores, and negatively with a math anxiety index. Standing concluded, “... the major cause of the observed deficit is that the teaching and practice of basic arithmetic skills in North American schools and university systems has declined greatly in the last seven decades; no other interpretation appears plausible."

Inadequate math skills may contribute to student anxiety regarding quantitative courses in a business curriculum. Zanakis \& Valenzi (1997) found that students experience high anxiety about the adequacy of their mathematics and reasoning skills, and that this "reaction may be exacerbated because many students are often surprised to discover the extent to which statistics is used" in their fields of endeavor. They go on to assert that, "attitudes and perceptions about statistics influence students' grades in statistics courses, and, subsequently, the extent to which students use statistics in their careers. Preconceived notions about statistics, feelings of a weak mathematical background ... may increase student anxiety and fear in undergraduate statistics courses." Perhaps if the source of those "math skill inadequacies" can be identified and addressed, some of the anxieties experienced by students may be belayed. If so, the potential exists for students' perceptions of statistics to change, to improve. Such would be a positive outcome, given that past studies have shown that students perceive statistics to have little value in practice (Swanson, Meinert, \& Swanson, 1994), while surveys of business professionals consistently indicate statistical analysis is the most frequently needed quantitative methodology (Lane, Mansour, \& Harpell, 1993; Philip \& Schultz, 1994).

Not all studies point to the importance of basic mathematical skills, however, in influencing or predicting performance in university business curriculum courses. In a study by Cohn, et al (1998), results do not indicate a need for math prerequisites for principles of economics courses. They found no significant effects of a math background on learning/performance in a principles of economics course. Giambra $(1970,1976)$ found that "success in the undergraduate statistics course had little to do with past mathematical background, but seemed to be directly related to a student's overall academic ability."

\section{METHODOLOGY}

This study has two objectives: the first is to measure, using a previously used instrument, the comprehension of basic mathematical skills of students enrolled in a business statistics course at a large regional university, and to determine if the scores earned on the basic skills test are useful in forecasting student performance in the statistics class. The second objective is to gauge whether students' basic math skills have changed over time, given the heightened reliance on computer technology. Have those skills diminished or become obsolete in our computer/technology driven age?

In order to address the first of these objectives, a basic computational skills test was given to 238 students in statistics classes at the above-mentioned regional university on the first day of class. Students were given twenty minutes to complete the test, and the use of calculators was not permitted. Demographic characteristics for the participants are shown in Table 1 to follow.

Scores on the test were then correlated with the students' end-of-semester grades to determine if a significant relationship exists. If such a relationship exists, then faculty should be able to reasonably be able to predict which students may encounter inordinate difficulties, such that provisions can be made to better address the needs of those individuals.

Of additional interest was the determination of whether or not differences exist with respect to gender, college classification, and major area of study (business vs. non-business). Accordingly, tests of significance were performed by gender, classification, and major on both the skills test and final grade.

To address the second objective - have basic math skills changed over time - current survey results were compared to performance results from an identical survey given in 1992-93 to 430 students. 


\section{FINDINGS}

So, what is the status today? Can a simple 20-minute math skills survey reveal differences with respect to student performance by class standing, gender, major area of study, and can it serve as a predictor of student performance in a business statistics course? And do these test results reveal any changes over time - progression or regression - when compared with student performance from nearly 15 years ago?

Table 1 shows the percent responses for the demographic variables and final grades, as well as summary statistics for the scores on the math skills assessment test. As can been seen in Table 1, more than 55 percent of the participants were males. Forty-five percent were marketing majors, while slightly less than 12 percent were nonbusiness majors. Eighty-seven percent of the participants were either juniors or seniors. Fifty-three percent of the participants earned grades of A or B in the statistics course, while 21.8 percent earned grades of D or F.

Table 1

Demographic Characteristics and Test Score Statistics for Respondents $(n=238)$

\begin{tabular}{|c|c|}
\hline Demographic Characteristic & Percent of Respondents \\
\hline \multicolumn{2}{|l|}{ Gender: } \\
\hline Female & 44.5 \\
\hline Male & 55.5 \\
\hline \multicolumn{2}{|l|}{ Academic Major: } \\
\hline Accounting & 17.2 \\
\hline Business Administration/General Business & 0.8 \\
\hline Computer Information Systems (CIS) & 9.7 \\
\hline Economics & 7.1 \\
\hline Finance & 2.5 \\
\hline Management & 5.9 \\
\hline Marketing & 45.0 \\
\hline Non-Business & 11.8 \\
\hline \multicolumn{2}{|l|}{ Classification: } \\
\hline Freshman & 0.0 \\
\hline Sophomore & 10.9 \\
\hline Junior & 43.3 \\
\hline Senior & 43.7 \\
\hline Graduate Student & 2.1 \\
\hline \multicolumn{2}{|l|}{ Score on Math Skills Assessment Test (40 possible): } \\
\hline 27 or less & 28.2 \\
\hline $28-31$ & 27.3 \\
\hline $31-34$ & 23.5 \\
\hline 35 or more & 21.0 \\
\hline \multicolumn{2}{|l|}{ Mean score $=30.06 ;$ Standard Deviation $=5.51$} \\
\hline \multicolumn{2}{|l|}{ Final Grade in Statistics Class: } \\
\hline A & 23.9 \\
\hline $\mathrm{B}$ & 29.1 \\
\hline $\mathrm{C}$ & 25.2 \\
\hline $\mathrm{D}$ & 12.4 \\
\hline $\mathrm{F}$ & 9.4 \\
\hline
\end{tabular}

Table 2 shows the breakdown of test scores by several different demographic variables, and by final grades in the statistics class, as well as results of significance tests. As the table illustrates, sophomores, juniors, and 
seniors had about the same average scores on the math skills test. The same may be said for business and nonbusiness majors, with both groups averaging between 73 and 75 percent correct responses (not significantly different).

When compared by gender, males had a significantly higher average score than did females (77.1 percent vs. 72.7 percent, respectively). Lastly, when comparing math skills scores to final statistics grades, students with higher statistics grades had significantly higher scores on the skills test. The coefficient of correlation was computed to be +.469 , which was significant at the .001 level. The interpretation is that approximately 22 percent of the variation in final course grades is explained by the variation in basic math skills, as measured by the test instrument. Alternatively, approximately 22 percent of the change in students' grades were explained by their skill level in mathematics.

Table 2

Math Skills Test Scores by Demographic Variables

\begin{tabular}{|c|c|c|c|c|c|c|}
\hline Classification: & $\mathbf{n}$ & $\begin{array}{c}\text { Mean Score } \\
\text { on Math } \\
\text { Skills Test }\end{array}$ & $\begin{array}{c}\text { Standard } \\
\text { Deviation on } \\
\text { Math Skills } \\
\text { Test }\end{array}$ & $\begin{array}{l}\% \text { Correct } \\
\text { on Math } \\
\text { Skills Test }\end{array}$ & $\begin{array}{c}\mathbf{t} / \mathbf{F} \\
\text { stat. }\end{array}$ & p-value \\
\hline Sophomore & 26 & 29.73 & 5.13 & 74.3 & \multirow[b]{3}{*}{0.557} & \multirow[b]{3}{*}{.573} \\
\hline Junior & 103 & 30.50 & 5.46 & 76.3 & & \\
\hline Senior or Higher & 109 & 29.73 & 5.65 & 74.3 & & \\
\hline \multicolumn{7}{|l|}{ Major: } \\
\hline Business & 210 & 30.15 & 5.49 & 75.4 & \multirow[b]{2}{*}{0.685} & \multirow[b]{2}{*}{.494} \\
\hline Non-business & 28 & 29.39 & 5.71 & 73.5 & & \\
\hline \multicolumn{7}{|l|}{ Gender: } \\
\hline Female & 106 & 29.09 & 5.99 & 72.7 & \multirow[b]{2}{*}{-2.458} & \multirow[b]{2}{*}{$.015^{*}$} \\
\hline Male & 132 & 30.84 & 4.97 & 77.1 & & \\
\hline \multicolumn{7}{|l|}{$\begin{array}{l}\text { Final Grade in } \\
\text { Statistics: }\end{array}$} \\
\hline $\mathrm{A}$ & 56 & 34.05 & 3.51 & 85.1 & \multirow[b]{5}{*}{17.414} & \multirow[b]{5}{*}{$.000 * *$} \\
\hline B & 68 & 30.54 & 4.48 & 76.4 & & \\
\hline $\mathrm{C}$ & 59 & 29.03 & 5.38 & 72.6 & & \\
\hline $\mathrm{D}$ & 29 & 26.72 & 5.80 & 66.8 & & \\
\hline $\mathrm{F}$ & 22 & 26.09 & 5.95 & 65.2 & & \\
\hline
\end{tabular}

*Significant at alpha $=.05$

$* *$ Significant at alpha $=.001$

Table 3 shows breakdowns and significance tests of final statistics grades by math skills scores (on median break), and by demographic variables. Again, sophomores, juniors, and seniors had about the same final average grades in the statistics class. Business and non-business majors had about the same average course grades. The same can be said for male and female students. However, students who scored higher than 31 on the math skills test (the median break, as noted earlier) had a significantly higher final grade in the statistics course than those who scored 31 or less on the test. This was to be expected, since the correlation between these two variables was significant, as mentioned earlier. 
Table 3

Final Grades in Statistics Classes by Demographic Variables

\begin{tabular}{|c|c|c|c|c|c|}
\hline Classification: & $\mathbf{n}$ & $\begin{array}{l}\text { Final statistics } \\
\text { Grade*** }\end{array}$ & $\begin{array}{l}\text { Standard } \\
\text { Deviation on } \\
\text { Final Grade in } \\
\text { Statistics } \\
\end{array}$ & $\begin{array}{l}\mathbf{t} / \mathbf{F} \\
\text { stat. }\end{array}$ & p-value \\
\hline Sophomore & 26 & 2.58 & 1.33 & \multirow[b]{3}{*}{0.186} & \multirow[b]{3}{*}{.830} \\
\hline Junior & 102 & 2.47 & 1.28 & & \\
\hline Senior or Higher & 106 & 2.42 & 1.19 & & \\
\hline \multicolumn{6}{|l|}{ Major: } \\
\hline Business & 206 & 2.48 & 1.29 & \multirow[b]{2}{*}{0.615} & \multirow[b]{2}{*}{.539} \\
\hline Non-business & 28 & 2.32 & 1.06 & & \\
\hline \multicolumn{6}{|l|}{ Gender: } \\
\hline Female & 104 & 2.41 & 1.35 & \multirow[b]{2}{*}{-0.481} & \multirow[b]{2}{*}{.631} \\
\hline Male & 130 & 2.49 & 1.16 & & \\
\hline \multicolumn{6}{|c|}{$\begin{array}{l}\text { Math Skills Test Score } \\
\text { (median break): }\end{array}$} \\
\hline 31 or Less & 129 & 2.05 & 1.19 & \multirow[b]{2}{*}{-6.010} & \multirow[b]{2}{*}{$.000^{* *}$} \\
\hline Higher than 31 & 105 & 2.96 & 1.13 & & \\
\hline
\end{tabular}

*Significant at alpha $=.05$

$* *$ Significant at alpha $=.001$

$* * * \mathrm{~A}=4.00 ; \mathrm{B}=3.00 ; \mathrm{C}=2.00 ; \mathrm{D}=1.00 ; \mathrm{F}=0.00$

Finally, are students today (2006/2007) performing at a higher level than those who participated in the math skills survey in 1992/1993? The survey results shown in Table 4 below indicate that they are not. In fact, the 2006/2007 students had a significantly lower average score on the math skills test than did the 1992/1993 students, at a .001 alpha level.

Table 4

Math Skills Test Scores By Year

\begin{tabular}{|c|c|c|c|c|c|}
\hline Classification & $\mathbf{n}$ & Mean Score & Std. Dev. & t-Stat. & p-value \\
\hline $1992 / 1993$ & 430 & 31.47 & 4.774 & & \\
\hline $2006 / 2007$ & 238 & 30.06 & 5.447 & 3.48 & $.0005^{*}$ \\
\hline
\end{tabular}

$*$ Significant at alpha $=.001$

\section{SUMMARY}

When it comes to basic math skills for college students, deficiencies remain. While some differences in performance levels exist (males vs. females, and in the previous study, business vs. non-business majors), overall performance continues to be disappointing, with college students averaging approximately 75 percent correct responses on a basic math skills test.

It may be somewhat gratifying, however, that a simple 20-minute test may be useful in identifying students who are apt to encounter inordinate difficulties in a quantitative course like business statistics. In our current study, approximately 22 percent of the variation in the students' final grade in the business statistics classes was explained by differing levels of mathematics skills as measured by our test instrument. For students with difficulties in quantitative skills, concerned faculty, with only minor accommodations, may be in a position to address the particular needs of those individuals, hopefully enhancing these students' potential for success in such courses. 


\section{FOOTNOTES}

1. Henry, Tamara, U.S. Students Lag Behind Others, Associated Press, Washington, D.C., printed in the Park City Daily News, Bowling Green, Kentucky, February 5, 1992.

\section{REFERENCES}

1. Cohn, E. (et al), The Effects of Mathematics Background on Student Learning in Principles of Economics, Journal of Education for Business, 1998, Vol. 74, No. 1.

2. $\quad$ Cornwall, C. Why Johnny Can’t Add, Reader's Digest, February 1999, Vol. 154, pp. 38-43.

3. Giambra, L., Mathematical Background and Grade-point Average as Predictors of Course Grade in an Undergraduate Behavioral Statistics Course: A Replication, Teaching of Psychology, Dec 1976, Vol. 3, No. 4, pp. 184-185.

4. Henry, Tamara, U.S. Students Lag Behind Others, Associated Press, Washington, D.C., printed in the Park City Daily News, Bowling Green, Kentucky, February 5, 1992.

5. Hume, W.E., The Opportunity Plan: Arithmetic, Senior Third Class, 1932, Toronto; Thomas Nelson \& Sons.

6. Jones, Thomas W., Assessment of Students' Comprehension of Fundamental Mathematical Skills: A Preliminary Study, Proceedings of the Decision Sciences Institute, San Diego, California (November 1990), pp. 608-609.

7. Jones, Thomas W., Assessment of Students' Comprehension of Fundamental Mathematical Skills: An Updated Study, Proceedings of the Decision Sciences Institute, Miami Beach, Florida (November 1991), p. 447.

8. Lane, M.S., Mansour, A.H., \& Harpell, J.L., Operations Research Techniques: A Longitudinal Update, Interfaces, 1993, Vol 23, No. 2, pp. 63-68.

9. Noser, Thomas C., Assessing Basic Mathematical Skills of Business and Non-business Students, Proceedings of the Decision Sciences Institute, San Francisco, California (November 1992), pp.276-278.

10. Philip, G.C., \& Shultz, H.K., Operations Research In Medium-Sized Companies and the Microcomputer Revolution: Educational Implications, Journal of Education for Business, 1994, Vol. 69, No. 4, pp. 217 221.

11. Pinney, W.E., and Jaska, Patrick, Assessing the Mathematical Skills of Business Students, Proceedings of the Decision Sciences Institute, Miami Beach, Florida (November 1991), p. 446.

12. Standing, L.G., Why Johnny Still Can't Add: Predictors of University Students' Performance On An Elementary Arithmetic Test, Social Behavior and Personality, 2006, Vol. 34, No. 2, pp. 151-160.

13. Swanson, J.C., Meinert, D.B., \& Swanson, N.E., Business Communications: A Highly Valued Core Course in Business Administration, Journal of Education for Business, 1994, Vol. 69, No. 4, pp. 235-239.

14. Zanakis, S.H., \& Valenzi, E.R., Student Anxiety and Attitudes in Business Statistics, Journal of Education for Business, 1997, Vol. 73, No. 1. 